\title{
Relationship Between School Feeding Programme and the Pupils' Effectiveness in Learning in Public Primary Schools in Kitui County
}

\author{
Evelyne Mwendwa \& Justus Gori \\ Maasai Mara University, P.O Box 861-20500, Narok \\ Email:mwendwaevelyne60@gmail.com \\ Dr. Justus Mchoma Gori,PhD School Of Education Maasai Mara University, \\ P.O Box 861-20500, Narok, Kenya. \\ Cell: +254706715203, Email: mchomagori@yahoo.com. \\ Garissa university College P.O. Box 1801-70100 \\ Email:mochomagori@yahoo.com.
}

DOI: $10.31364 / S C I R J / v 7 . i 7.2019 . P 0719667$

http://dx.doi.org/10.31364/SCIRJ/v7.i7.2019.P0719667

\begin{abstract}
To participate effectively in the economic development of the country, hunger ought to be controlled. This can be done if feeding programme are introduced in schools. School Feeding Programme (SFP) was initiated in Kenya in 1979 with provision of milk packets to the pupils and it was fully implemented in 1980 by the government of Kenya with collaboration with World Food Programme (WFP), though it has not led to desired outcome in many parts of the country. The objective of this study was to assess the relationship between SFPs and the pupils' retention in public primary schools in Kitui County. The study intended to assess retention as one of the indicators of effectiveness in learning. The study used Classical Liberal Theory of equal opportunity and Maslow's theory of Human motivation. The researcher used survey research design. The target population was 374 primary schools under feeding programme in Kitui County. The sample size was 112 schools which are $30 \%$ of the target population. These schools were sampled randomly. The researcher also randomly sampled five percent (19) class seven teachers of the target population which made a total of 131 respondents. The research instruments used by the researcher were the questionnaires for head teachers and the interviews for class seven teachers' representatives. To test validity of the research instruments, the researcher did piloting in two schools (10\%) of the sample target 19 class seven teachers. The researcher also discussed the instruments with her supervisors who are experts in her area of study and was advised accordingly. Reliability of the research instruments was calculated using test-retest method. Quantitatively collected data was analyzed using descriptive statistics and Pearson $r$ with the help of SPSS software while qualitatively collected data was analyzed using Focus by Question Analyses Strategy. Analyzed results were presented using tables, graphs and pie-charts. The findings of the study may help the administrators and policy makers to lay down their strategies successfully. Results show that there was a significant relationship between school feeding program and pupils' retention, school feeding program and pupils' transition, Findings from the interviews further confirmed that there was unwavering agreement among class seven teachers' representatives that school feeding program was positively associated with effectiveness in learning. The study concludes that school feeding program has significant influence on effectiveness in learning among primary school learners, hence the two hypotheses were therefore, rejected. The study recommends the county government to liaise with parents and guardians of primary school pupils in order to expand the school feeding program to include breakfast and supper so that more learners can be retained in school and their transition from a class to another enhanced. These findings will be beneficial to the Ministry of Education, parents as well as the administrators of the primary schools across the country.
\end{abstract}

\section{Keywords: Effectiveness, Feeding Programme, Retention, Learning, school}

\section{Introduction}

School Feeding Programme (SFP) can be used to address temporary hunger to make a significant contribution in the improvement of the pupil' retention. Kenya is a signatory to many international agreements that have among other things recommended the attainment of Universal Primary Education (UPE). School feeding programme is aimed at achieving this course in Kenya. When pupils feed in schools, wastage in education is minimized. Nwankwo (1981) defined educational wastage as an inefficient use of educational resources. He added that wastage involves, dropouts, repeaters pre-mature withdrawal, misguided types of education, un-employment of school leavers and even brain drain. Adesina (1983) described education wastage, from the perspective of the 
education planners as, when an investment does not produce either its desired or anticipated results or produces these results at a scale considerably lower than it was set for itself. All the above mentioned issues can be fully controlled if feeding programmes are fully introduced in schools, supported and implemented in totality in the whole country. Learners will be confined in schools and learn as per the individuals' rate of understanding. There will be no disturbance of movement here and then.

\section{Background of the study}

The availability of school meals is considered to have a positive effect on cognitive development and learning as a number of studies have maintained (Adelman, 2008; kristjansson, 2007).Investing in education is a key component which leads to the development of a country. Education is a fundamental right for a person for effective contribution to the development of a country since it enhances equity, diversity and lasting peace as stipulated by World Education Forum Education for all in 2000. Successful effectiveness in learning can be sustained through provision of food which can be done through implementation of feeding programmes in schools. According to the school feeding programme handbook (2006), the objectives of the school feeding programme are to: (1) to improve the primary school enrolment, enhance the attendance rates and reduce the drop-out rates due to hunger. (2) To reduce the disparities in enrolment, attendance rates and gender. (3) To improve the children's capacity to concentrate and assimilate information by reliving short term hunger. (4) Enhance the involvement rates and increase enrolment of children in the disadvantaged counties 5) To contribute to the improvement of nutrition intake and general health of the children from low income families 6)Improving pupils' attention and participation in classroom activities 7)Enhancing pupils' transition from a class to another class. World food programmes (WFP), has used food to facilitate to educate poor children for more than forty years and it has been the main organizer for SFP in the developing world. Subsidized school lunches began in the US in 1946 under the National school Act and since that time numerous studies have been conducted to determine the adequacy of these programmes and their relationship with children's effectiveness in learning. In 2009, the World Bank and the WFP published a joint review re-emphasizing the rationale and objectives of the feeding programmes. The three main objectives identified were to provide safety nets for families to absorb social and economic shocks effectiveness in learning and scholastic performance for the school-aged children and to enhance their health. There also other possible objectives of the school feeding programmes as follows, improvement of the nutritional status of children, to improve attendance of poor children who do not receive sufficient food at home or must walk very long distances to school. It also in improving pupils' attention and effectiveness in learning while in class. It encourages community participation implying that parents, teachers and other stake holders should be involved to lay the required arrangements before the onset of the feeding programme.

World Food Programme provides food assistance to schools in 29 countries in Africa (WFP, 2014). Many children were not able to benefit from the food provided by the WFP because their schools are not under feeding programmes. In Nigeria, which has one of the lowest enrolment rates in the world, a school Programmers was intended to be started so as to enhance attendance of normal and transhumant families and particularly girls. Areas with nomadic and transhumant population, the school year cannot commence until food stocks arrive (WFP, 1995, 1996). World Food pragramme offices are in Rome though it has field staffs in many developing countries. Sometimes there are no WFP officers stationed in a given country therefore, the resident representative of the united Nations Development Programme (UNDP) become the official representative of the world food Programme in that particular country for that particular time and this office can be helpful in that particular period.Partaining educational aspects with relationship to school feeding programmmes,some officers who are trained and skilled enough about school feeding issues are appointment to be in charge of those offices.However,specialized agencies of the United Nations (UN) such as World Health Organization (WHO),United Nations International Children's Emergency Funds (UNICEF),Food and Agricultural Organization (FAO) and United Nations Educational Scientific and Cultural Organization (UNESCO) can be called to assist. Most of the food provided to most schools is imported. It is important to make sure that the food provided to the schools is familiar and acceptable by the pupils to be fed in that area. It is also put into consideration if the imported food will change normal food habits for better or worse in terms of the countries own nutrition objectives. The imported food should also complement locally supplied foods so that the locals can replace the externally imported food if it is completely used. The government ought to contact through their channels the diplomatic representatives of the country from which they wish to receive their bilateral food aid. It should also be noted that most of the European economic communities provide food aid globally. Not all school feeding programmes were developed to support educational objectives but some catered for orphaned children and served the under- privileged children such as the street children and the needy children. School meals were one way of ensuring that children had equal educational opportunities. World food programme began operating in 1963 after the independence to December 1976 since this time; it has given food aid to pupils in different primary schools. Experts have discussed for quite a longer period whether primary school children are really the majority targeted by the school feeding programmes. School feeding programme helps and supports one of the basic needs for the human beings, education. Education is a human right and it is supported by school feeding programmes hence it can be justified in the economic terms as well it provides a basic economic right. 
School feeding programs are associated with retention of pupils across the world; hence there is existence of the program in many education systems across the world. According to the World Food Program (WFP). As described by WFP, almost every country across the world has a school program focused on feeding of the school children. As such, school feeding programs have been implemented in both developed and developing countries across the world. In developing nations, school feeding programs have a major goal of ensuring that there is increased learner`s concentration span by reducing short -term hunger. However, in developed countries such as the United States of America (USA), school feeding programs are focused to provision of a nutritious meals to learners at a lower cost.

In the US, the most popular school feeding program is the National School Lunch Program (NSLP), which is a federally supported school feeding program, feeding school children in public schools, non-profit schools, and residential clinical care institutions (NSLP, 2018). In England, the School Food Plan is the national school feeding program funded by the government. The program had a lunch take up of $38 \%$ in secondary schools and $44 \%$ in primary schools (LACA, 2013), offering meals constituting of fruits and starchy components. However, unlike the U.S. school feeding program, the School Food Plan does not promote a nutritious approach, for instance; only a few schools $(22.5 \%)$ provided fruits and vegetables per pupil per day, while $50 \%$ of secondary schools offered starchy food to students.

In Africa, school feeding program have been implemented to ensure short- term reduced hunger which would lead to increased school pupils' retention. The "Food for Education" program implemented by WFP in Tanzania has been essential towards promoting education within the country, since its inception, it has benefited about 200000 pupils in about 400 primary schools in 6 districts within Arusha and Manyara (WFP, 2010). The initiative has ensured that pupils with the 400 schools enjoy mid-day meals. In Kenya, school feeding program have been implemented since 1980s with varying degrees of success. They were originally focused in promoting enrollment and retention. The Kenyan Home Grown School Meals Program (HGSM) is designed as a safety net strategy to increase food supply, improve incomes and reduce hunger and malnutrition.

\section{Statement of the Problem}

Food has been acknowledged as one of the tools that help in the effectiveness in learning of primary school pupils. Education is one of the economic developmental factors in the world; therefore effective strategies for providing education to pupils should be well formulated especially in primary schools since they lay the learning foundation worldwide. Effectiveness in learning in Kitui County was not achieved positively as evidenced by the 2016 KCPE results; Kitui County was ranked position 37 out of the 47 counties in the nation. The enrolment rate was very high but the completion rate was very low (EMIS 2005). The county has low retention rates.

The county is among the counties with the feeding programmes but it did not indicate a positive image in effectiveness in learning in relation to retention instead the learning was relatively low. The available empirical studies show that school feeding programmme positively contributes to pupils' retention and reduces pupils' dropout in primary schools in many developing countries (Jomaa et al., 2011). According to reports from the kitui county office, many pupils and students especially from the poor families skipped school because they could not afford food and other basic necessities needed in school. This has caused a lot of concern to the authorities of the county. Governor Ngilu noted that education standards have deteriorated over the past years; she attributed the county's poor performance in the national examinations with the extreme poverty and lack of learning materials in many schools (Kituionline.com).

\section{Purpose of the Study}

This study was set to assess the relationship between school feeding programmes (SFP) and the pupils' effectiveness in learning by examining the following factor', retention of pupils in public primary schools in Kitui County, Kenya.

\section{Objective of the study}

This study was guided by the following objective

To find out how far the school feeding programmes have influenced primary school pupils' retention rates in Kitui County.

Research Hypothesis

This study was guided by the following hypothesis 
ISSN 2201-2796

“There is no significant relationship between school feeding programmes and the pupils' retention rates in Kitui County."

Theoretical Framework 
The study under investigation was guided by Classical Liberal Theory of Equal Opportunity and Maslow's Hierarchy of Needs Theory (Human Motivation).

\section{Classical Liberal Theory of Equal Opportunity}

This Theory was advanced by John Dewey in 1946. The theory expresses that there should be equal opportunities of similar treatment of people in every area including education as evidenced by education for all in Kenya. The basic assumption of this theory is that every child is born with innate talents and capabilities therefore; education systems should be designed with a view of a pupil taking advantage of the inborn talents that could accelerate social promotion (Sherman \& Wood 1982). This theory demands that opportunities including education to be availed to individuals at schools and barriers for instance hunger to be curbed through provision of food through school feeding programmes. This would enable the learners to be more effective in learning in relation to retention. This Theory suits this study because the independent variable (SFPs) will have effect on dependent variable (Effectiveness in Learning). When food is provided to schools it will enable pupils from different family backgrounds to access education equally and at ease. Free primary education and education for all may be achieved through the provision of food to the pupils at schools. The theory assumes that positive impact will be posted through high retention rates.

\section{Abraham Maslow's Theory of Human Motivation}

Another theory that has been used in this study is Abraham Maslow's theory of human motivation which was developed in 1943. The theory explains that at while human beings aim to meet their basic needs, they equally aim to meet successfully higher needs in the form of a pyramid as established by Maslow. Maslow's Hierarchy of needs have often been presented in a hierarchical pyramid with five levels with the largest and most fundamental at the bottom and the need for self-actualization at the top. At the base of the hierarchy are the physiological needs, followed by safety needs, love/belonging, esteem, and self-actualization, which is the topmost need at the top of the pyramid (Jerome, 2013).

\section{Conceptual Framework}

A conceptual framework shows the relationship between the independent and the dependent variables. The interaction of the variables' relationship is indicated by the arrows. In this study, the conceptual framework was based on the relationship between school feeding programme and the learners' effectiveness in learning in relation to pupils' retention. The feeding programme is the independent variable, while the factors affecting effectiveness in learning are the dependent variables as shown in the figure below.

Independent Variable

\begin{tabular}{|c|c|c|c|}
\hline $\begin{array}{l}\text { School Feeding } \\
\text { Programme } \\
\text { (SFP) }\end{array}$ & & & $\begin{array}{l}\text { Pupils' } \\
\text { Effectiveness in } \\
\text { learning }\end{array}$ \\
\hline $\begin{array}{l}\text { Consensus on } \\
\text { policy objectives }\end{array}$ & & & $\begin{array}{l}\text {-Learners' } \\
\text { retention rates }\end{array}$ \\
\hline $\begin{array}{l}\text { Appropriate } \\
\text { guidelines }\end{array}$ & $\begin{array}{l}\text { Availability of other } \\
\text { Learning Resources }\end{array}$ & & \\
\hline $\begin{array}{l}\text { Availability of } \\
\text { food supply }\end{array}$ & $\begin{array}{l}\text { Teachers' attitude towards } \\
\text { the SFP }\end{array}$ & g & \\
\hline Monitoring and & Parents' support on SFP & v7.i7.20 & \\
\hline
\end{tabular}


The study conceptualized on the relationship between SFP and learners' effectiveness in learning of the children attending primary schools. With food provided at school theoretically, the pupils would be expected to be receptive to learning. This would enhance positive effectiveness in learning. Pupils would desire to stay at school learning, there could be a few dropouts or any unplanned transfers, retention level will be optimal at all times. It comprises: Research design, location of the study, sampling techniques and sample size, research instruments, pre-testing, pilot study, Validity of the data Instruments, Reliability of the Research Instruments, data collection procedure, data analysis methods, presentation and ethical considerations.

\section{Research Design}

The study adopted survey research design. The use of surveys refers to an approach of collecting information through asking questions. It uses approaches such as focus group discussions, interviews, and questionnaires to ensure that questions are answered. Further, since it is difficult to ask questions to every individual in the population under study, a survey research design allows selection of a representative sample of participants that will be involved in the study, and the findings of the study applied to the larger population. Therefore, in a study such as this covering all primary schools in Kitui County, a survey research design is the most appropriate. To conduct a survey research design, the first step involves identification of the study population. This is followed by sampling the study population to identify a representative sample that will take part in the study. After identification of the study sample, a data collection tool is identified and designed to suit the identified respondent characteristics. Data collection is then scheduled and performed, while data is analyzed through appropriate techniques.

The researcher personally administered the questionnaires to the head teachers and left them to work at their own phase however the researcher was there for any clarification. The researcher also interviewed the class seven teachers' representatives and recorded down the responses given by the teachers. These responses were later used by the researcher for analyzing the qualitative data. This created high response rates as well as good return rate. The researcher compared responses from the head teachers and the ones from the class seven teachers; he then got similarities and differences that helped the researcher to get the relationship between school feeding programme and the pupils' effectiveness in learning in relation to retention. Survey research design is less time consuming and it is not expensive as compared to other designs. The design is also convenient for data collection.

\section{Target Population}

The target population for this study was 374 schools, the only schools under feeding Programme. The study targeted the head teachers and the class seven teachers of these schools. The impact of school feeding programs is felt at the school level. Therefore, teachers are the primary observers of the impacts of the school feeding programs in relation to this study. Therefore, they have the most reliable information concerning the program than any other stakeholder.

6. Data Collection Procedure

An introduction letter was obtained from the school of education postgraduate department, Maasai Mara University to solicit approval to conduct the study from respective selected public primary schools in Kitui County. The researcher proceeded to National Committee for Science Technology and Innovation (NACOSTI) to get research authorization permit. The researcher then proceeded to the Education county director and the county commissioner Kitui County to seek permission to conduct the study and collect data from the selected public primary schools. Respondents were explained about the study and were requested to sign the consent form. The researcher had produced enough questionnaires for all the head teachers and an interview question form for the class seven teachers. During the administering of the questionnaires, respondents were requested to fill the questionnaires by rating using the numbers assigned indicating the degree of their opinion. The researcher visited the schools, introduced herself to the head teachers and explained her intention. The researcher asked the head teacher to introduce her to the class seven teachers. With this assistance, the researcher administered the questionnaires to the head teachers personally and collected them the same day, ensured that they were all filled and returned. The researcher also conducted interviews to the class seven teachers and assured the participants of confidentiality. This determined high response and return $r$

6. Data Analysis 
First, the survey findings pertaining responses from the head teachers' concerning the head teachers' opinions assessing the relationship between school feeding programme and the learners' effectiveness in learning was presented using tables. The information in these tables showed the head teachers' views pertaining the relationship between school feeding programme and the learners' retention. The quantitative data was presented in a more manageable form. Qualitative data was also presented by analyzing the answers given by various teachers pertaining various interview questions comparison was made and a certain conclusion was arrived at. This study used Pearson $r$ to test quantitatively collected data from the head teachers. Therefore, the two main variables involved were the school feeding programs and retention of primary school pupils.

\section{Data Analysis and Presentation}

Based on the findings, the researcher further presents the discussion of the results detailing both quantitative and qualitative analysis. To establish existence of relationship, Pearson $r$ was employed at $95 \%$ confidence interval. The p-values obtained were compared with an alpha level of 0.05 and used as a basis for rejecting or failing to reject the null hypotheses. Results were presented using tables and graphs. Data analysis results from head teachers were compared with interview results using verbatim from various respondents before discussions were done.

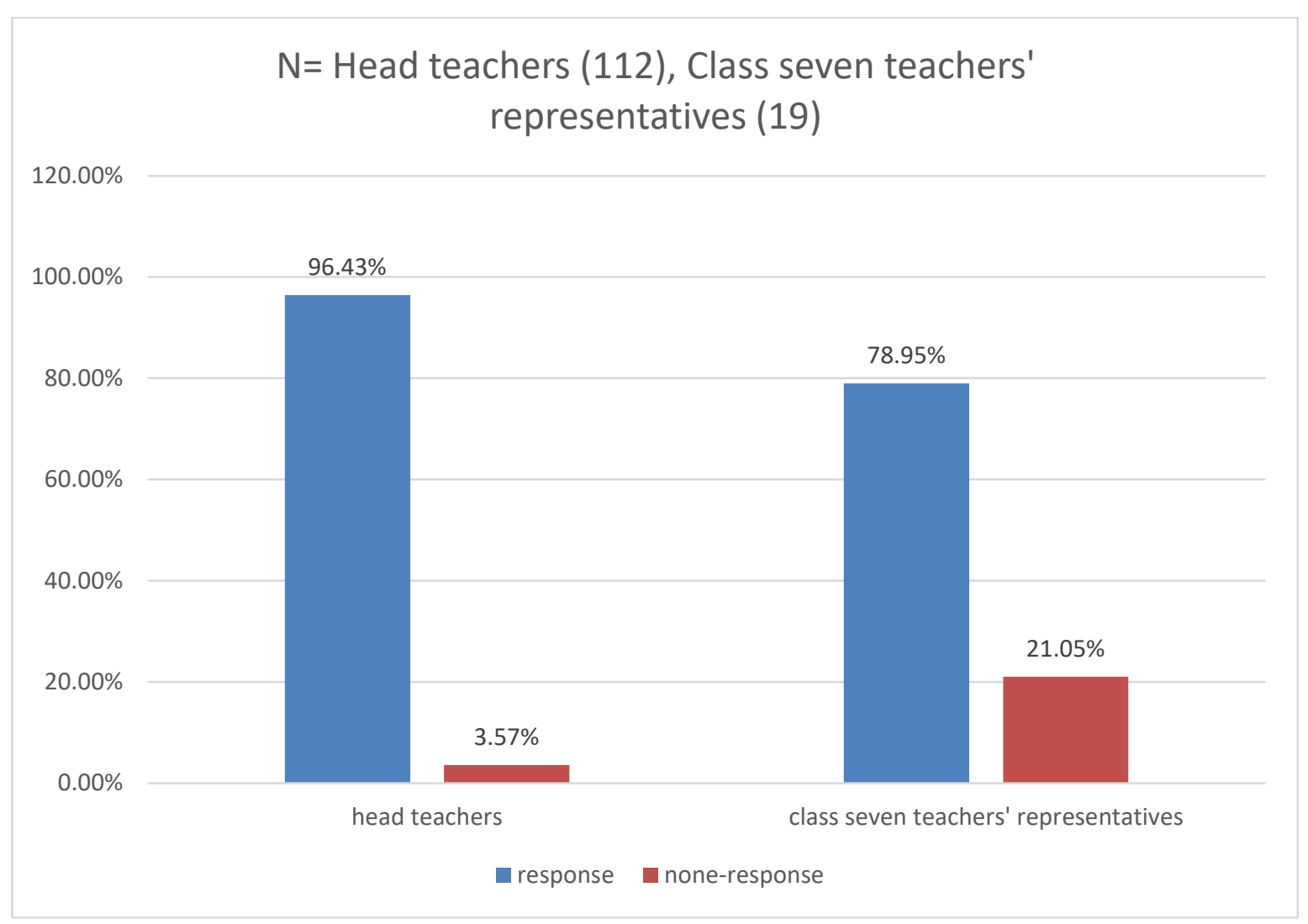


From the findings shown in the above figure, $96.43 \%$ of the targeted head teachers successfully filled and returned their questionnaires while only $3.57 \%$ did not. On the other hand, $\mathbf{7 8 . 9 5 \%}$ of the class seven teachers' representatives fully participated in the interview. Creswell (2014) asserts that a response rate of $70 \%$ and above is adequate to validate the findings of a stu13. Relationship between School Feeding Program and Primary School Pupils' Retention Rates in public primary schools in Kitui County.To get information on the retention rates, the researcher had some questioners for the head teachers to answer giving their views on the extent that they agreed on items on retention. Their responses are shown in the table below. Head teachers were asked to indicate their opinions in regard to the role of SFP on retention of pupils. Responses were placed in a four likert scale of 1 to 4 , where 1 was strongly agree and 4 was strongly disagree. All respondents were requested to tick only one choice, hence multiple responses were not allowed in this case.

Head teachers' opinion on the influence of SFP on retention rates in public primary schools in Kitui County

$\mathbf{F}$

$\begin{array}{lllll}\begin{array}{l}\text { Strongly } \\ \text { agree }\end{array} & \text { Agree } & \text { Disagree } & \begin{array}{l}\text { Strongly } \\ \text { disagree }\end{array} & \text { Total }\end{array}$

Retention rate of the pupils is very high in $\mathbf{F}$

52

46

6

4

108

this school

$\% \quad 48$.

42.6

5.6

3.7

100

School Feeding Programme plays a great F

68

36

2

2

108

deal of retaining pupils in your school

$\% \quad 63$

1.9

1.9

100

Retention rate has dropped since the F introduction of the School Feeding Programme

\section{F}

2

$\mathbf{0}$

69

37

108

$\% \quad 1.9$

$\mathbf{0}$

63.9

34.3

100

Due to School Feeding Programmme, the F F $\quad 58$

44
retention rate in your school is quite high

$\% \quad 53.7$

40.7

3.7

1.9

100

Drop-out rate has increased since the 
introduction of the School Feeding

Programme.

$\begin{array}{llllll}\% & 5.6 & 0 & 40.7 & 53.7 & 100\end{array}$

From the findings indicated in the above table, most of the head teachers $(\mathbf{4 8 . 1 \% )}$ strongly agreed that retention rate of their pupils was very high in their respective schools. Less than $10 \%$ of the head teachers said that retention rate in their schools was not high, an implication that head teachers felt that the situation was okay and not much problem existed. Basically, head teachers felt that there was no much problem with retention, with most of them attributing School Feeding Program to high retention. In fact, $63 \%$ of the head teachers strongly agreed that SFP was responsible for the high retention rates. Again, only less than $5 \%$ of the head teachers opined that SFP was not responsible for the high retention rates. The findings further show that majority of the respondents $(63.9 \%)$ disagreed that retention had dropped since the introduction of SFP. However, 34.3\% of them had opposite opinion (that SFP led to dropped retention rates). Moreover, respondents denied that absenteeism rate had increased under the curtsey of SFP; for instance, 53.7\% of the respondents strongly disagreed that drop-out rate had increased due to school feeding programmme.After the head teachers gave their opinion on their views on the influence of SFP on pupils' retention, the researcher took a step of testing the relationship between school feeding programme and the pupils' retention rates. The researcher sought to test the hypothesis that there is no significant relationship between school feeding programme and the pupils' retention rate in the public primary schools in Kitui County so as to compare it with the head teachers opinions on the influence of the school feeding program on the pupils' retention .To get clear information on this, the researcher conducted a Pearson Moment Correlation Coefficient (r) and employed $95 \%$ confidence level so as to help test the hypothesis correctly.

Pearson relationship between provision of school meals and pupils' retention in public primary schools in Kitui County

Provision of school meals 
Correlation is significant at the 0.05 level $(2$-tailed $), \mathrm{df}=106, \mathrm{p}<0.05$.

According to the results displayed in the above table on the relationship between school feeding programme and the pupils' retention, it is clearly seen that there was a significant relationship between school feeding programme and the pupils' retention. The results obtained were, $r(108)=0.79, p<0,05$.Threfore, the hypothesis that, there is no significant relationship between school feeding programme and the pupils' retention is therefore rejected. This implies that SFP affected retention of pupils in schools positively therefore provision of school meals lead to better retention while poor or no provision of school meals would lead to poor retention of pupils in schools. The findings in this study show that head teachers had a positive opinion that SFP was useful to ensure continued retention of pupils in schools. This can be confirmed to be true because different respondents attempted their questionnaires at their own locality and at different times though they came up with the same opinion of SFP having a positive effect on the pupils' retention. The findings send a clear indication that head teachers in public primary schools in Kitui County were in support of the SFP and that they had noticed a significant change since the implementation of the SFPs.

Similarly, teachers' representatives were asked to comment about the extent to which SFP had influenced retention rate of pupils in the schools they represented. Most of them were of the opinion that SFP was a crucial intervention that had helped pupils in Kitui County to improve on their retention in school. In fact, out of the 15 teachers involved in the study, all but one expressed positive remarks in regard to the role of SFP in enhancing pupils' retention in schools. Most of them argued that Kitui being a semi-arid region experiences drought and hunger, hence some children do not get enough food at home. As such, there was need to improve their retention rates through provision of meals in schools on daily basis.

\section{Summary, Conclusion and Recommendation}

In this chapter, the researcher present It can be stated that the researcher was able to address all the research objectives adequately and with clarity. In general, the objectives were based on establishing the relationship between school feeding program and primary school pupils': retention rates.

\section{Summary of the Findings}

Relationship Between School Feeding programmes and the pupils' Retention Rates 
The objective of this study was to establish the relationship between feeding program and primary school pupils' retention rates. The findings of the study have shown that school feeding program had tremendous influence on retention. Results from the head teachers show that there was an unpaneled approval of school feeding program as an effective intervention to improve retention of pupils in public primary schools. Moreover, most class seven teachers' representatives explained that many excuses coming from pupils as reasons for dropping out of school had reduced significantly. Drop-out rate had reduced significantly.Both teachers and head teachers were of the opinion that the main reasons why there were high levels of drop-out. Dryness and poverty are the inherent characteristics that are used to describe the region in many developmental realms. As such, retention of children in schools remains difficult in situations where meal plans are not well defined or rather consistent. Both head teachers and class seven teachers' representatives were therefore, apprehensive that school feeding program had solved many of these problems, since primary school children simply require proper nutritional arrangements besides other social and emotional attentions. The results from the class seven teachers' representatives have also shown that there were significant changes in pupils' retention after introduction of school feeding program. The findings show that retention before introduction of school feeding program was really poor as explained by some of the teachers in their verbatim. The responses from the teachers show that there were great differences in retention before and after introduction of school feeding program, hence the researcher finds that school feeding program led to exponential increase in retention rates.

Correlation findings further show that there was a significant correlation between school feeding program and pupils' retention rate. The findings show that improvement of school feeding program in terms of providing more and balanced meals would lead to better retention of pupils in class and other school activities. The findings from the head teachers' opinions on the relationship between school feeding program and pupils' retention were therefore consistent with the findings from the teahers'representatives and the other study findings. There was a significant relationship with retention of primary school pupils. The results from interviews further confirmed that school feeding program had led to tremendous reduction in pupils' drop-out rates. The study finds a significant relationship, hence the hypothesis that 'there is no significant relationship between school feeding program and retention of pupils' is hereby rejected.

\section{Recommendations}

1. The study recommends the county government to liaise with parents and guardians of primary school pupils in order to expand the school feeding program to include breakfast and supper so that more learners can be retained in school.

2. The researcher further recommends that the head teachers and teachers to take advantage of school feeding program to ensure more pupils are retained in the schools till they complete their courses within their respective cohorts.

3. The study recommends teachers and the school management to ensure learners attend school as expected, by ensuring all the pupils benefit maximally from the provision of food in school.

4. The study further recommends the national government to further improvise more strategies that will ensure more learners are retained in school

5..The researcher recommends that the county government to ensure that all the schools in Kitui County have school feeding programmes and support them fully.

6. The study recommends that, the kitui county government to take the responsibility of implementing school feeding programmes in all1. primary schools so as to enhance learning in the county. 


\section{Suggestions for Further Study}

The researcher suggests further studies to be conducted on methods used to implement the school feeding program, in order to ensure that the intended purpose if fulfilled.

The study further recommends further study on school feeding program disparities existing between boarding and day primary schools as well as the differences in implementation of their programs. 


\section{REFERENCES}

Adam, J.Kamuzora, F. (20080. Research methods for business and social studies, Morogoro; Mzumbe book project.

Adekunle, T., \& Ogibogu, C. (2016). The Effects of School Feeding Programme on Enrolment and Performance of Public Elementary School Pupils in Osun State, Nigeria. World Journal Of Education, 6(3). doi: 10.5430/wje.v6n3p39

Ademokun, O., Osungbade, K., \& Obembe, T. (2014). A Qualitative Study on Status of Implementation of School Health Programme in South Western Nigeria: Implications for Healthy Living of School Age Children in Developing Countries. American Journal Of Educational Research, 2(11). doi: :10.12691/education-2-11-12

Adrogué, C., \& Orlicki, M E. (2016). Do In-School Feeding Programs Have Impact on Dropouts? The Case of Public Argentine Schools.

Academic Performance and

Ahmed, A. (2004). Impact Of Feeding Children In School: Evidence From Bangladesh [Ebook].

Ahmed, A. U. (2000). Targeted Distribution. In Out of the shadow of famine: Evolving food markets and food policy in Bangladesh, ed. R. Ahmed, S. Haggblade, \& T. E. Chowdhury, 213-231. Baltimore, Johns Hopkins University Press.

Ahmed, A. U. (2004). Assessing the performance of conditional cash transfer programmes for girls and boys in primary and secondary schools in Bangladesh. Project report prepared for the World Bank. Washington, D.C.: International Food Policy Research Institute.

Ahmed, A. U., \& Del C.N. (2002). The food for education programme in Bangladesh: An evaluation of its impact on educational attainment and food security. Discussion Paper 138. Food Consumption and Nutrition Division. Washington, D.C: International Food Policy Research Institute

Ahmed, A.U. (2004). Impact of feeding children in school; Evidence from Bangladesh, Washington, DC: International food policy research Institute (IFPR).

Aila, B. (2012). The Impact And Challenges Of School Feeding Programme In Enhancing Access To Primary Education In The Unplanned Settlements Of Kibera In Nairobi[Ebook]. Retrieved from http://irlibrary.ku.ac.ke/bitstream/handle/123456789/5491/Ouko\%20Boniface\%20Aila.pdf?sequence=3 
Ajani, O. (2012). The Effect Of School Feeding Programme On Primary School Attendance In Rural Areas Of Lagos State, Nigeria. African Journal For The Psychological Study Of Social Issues, 12(1).

Arumugam, A. (2016). Understanding School Feeding Programmes in India and Tamil Nadu in addressing Classroom Hunger. IRA-International Journal Of Education \& Multidisciplinary Studies, 4(1).

Atta, G., \& Manu, D. (2015). Ghana School Feeding Program: A Retrospective Review[Ebook]. Retrieved from http://www.ijird.com/index.php/ijird/article/viewFile/75321/58614

Barnabas, K. (2014). School Feeding Programme And Its Influence On The Preschool Children Academic Performance In

Kaplong Zone Bomet County. [Ebook]. $\quad$ Retrieved
http://cees.uonbi.ac.ke/sites/default/files/cees/barnabas\%20project_0.pdf

Best, J. W\&Kahnj. (2000). Research in education; New Delta: Prentice Hall India.

Bultenheim a.m., alderman H. \& Friedman J. (2011).Impact evaluation of feeding programme in LAOPDR.Word Bank policy research working paper services, 5518.

Chatterjee, R. (2016). The Evolution of Brazil's National School Feeding Program. Retrieved from https://pulitzercenter.org/reporting/evolution-brazils-national-school-feeding-program

Chaula, E. (2015). An Assessment Of Influence Of School Feeding Program On Pupils' Enrollment, Attendance And Academic Performance In Primary Schools In Njombe District, Tanzania [Ebook]. Retrieved from http://repository.out.ac.tz/1358/1/EVARISTO___RESEARCH.pdf

Chelangat, C. (2016). The Relationship between School Feeding Programmes and School Attendance and Enrolment among Preschool Children in Chepalungu Sub-County, Bomet County, Kenya [Ebook]. Retrieved from http://irlibrary.ku.ac.ke/bitstream/handle/123456789/14973/The\%20relationship\%20between\%20school\%20feeding\%20program mes.pdf?sequence $=1$

Chepkwony, B., Kariuki, B., \& Kosgei, L. (2013). School Feeding Program and Its Impact on Academic Achievement in ECDE in Roret Division, Bureti District in Kenya. Journal Of Emerging Trends In Educational Research And Policy Studies. Retrieved from http://jeteraps.scholarlinkresearch.com/articles/school\%20feeding.pdf

Cheserem, K, G. (2013). Influence of School Feeding Programme on Pupils' Participation in Public Primary Schools in Baringo North, Baringo County - Kenya. Unpublished Thesis University of Nairobi.

Cheung, M., \& Berlin, M. (2014). The Impact of a Food for Education Program on Schooling in Cambodia. Asia \& The Pacific Policy Studies, 2(1), 44-57. doi: 10.1002/app5.21 
Clay, E., \& O. Stokke. (2000). Food aid and human security book, Frank Cass, EADI, and ODI. Functions of school children of differing nutritional status.American Journal of Clinical

darko, B. (2014). The School Leadership Views on the Impact of the National School Feeding Programme in Ghana The Case Study of Adumanu M/A and Ayaasi D/A Primary Schools [Ebook]. Retrieved from https://jyx.jyu.fi/bitstream/handle/123456789/44720/1/URN\%3ANBN\%3Afi\%3Ajyu-201411223340.pdf

Dayuor, F. (2015). Effect of the National School Feeding Programme on Pupils' Enrolment, Attendance and Retention: A Case Study of Nyoglo of the Savelugu-Nantong Municipality, Ghana. Canadian Journal Of Behavioural Science, 5(3). doi: 10.9734/BJESBS/2015/14271

Dei, F. (2015). An Evaluation of the School Feeding Programme: A Case Study of Magog Primary School [Ebook]. Retrieved from http://uir.unisa.ac.za/bitstream/handle/10500/18779/dissertation_dei_fa.pdf?sequence=1\&isAllowed=y

Dheresa, D. (2008). Education in Focus: Impacts of School Feeding Program on School Participation: A Case Study in Dara Woreda of Sidama Zone, Southern Ethiopia [Ebook]. $\quad$ Retrieved from https://brage.bibsys.no/xmlui/bitstream/handle/11250/187763/Final\%20Master\%20Thesis\% 20\%28Desalegn\%20Keba\%2 0Dheressa \% 29.pdf?sequence $=$

Doets, E. (2007). Quality evaluation and update of the Mali food composition table (TACAM 2004) .Wageningen University.

Drake, L., Woolnough, A., Burbano, C., \& Bundy, D. (2016). Global School Feeding Source Book: Lessons from 14 countries [Ebook]. Imperial College Press.

Falade, O., Otemuyiwa, I., Oluwasola, O., Oladipo, W., \& Adewusi, S. (2012). School Feeding Programme in Nigeria: The Nutritional Status of Pupils in a Public Primary School in Ile-Ife, Osun State, Nigeria. Food And Nutrition Sciences, 03(05), 596-605. doi: 10.4236/fns.2012.35082

Finan, T. (2010). Impact Evaluation of WFP School Feeding Programmes in Kenya (1999- 2008): A Mixed-Methods Approach. Rome: World Food Programme.

Galloway, R. (2009). School Feeding: Outcomes and Costs. Food and Nutrition Bulletin.

Gay, L.R. (1992). Education Research: Competence for Analysis and Application. 4th Edition.New York. Macmillan Publishers.

Gete, T. (2017). Over 1.3m Students to Benefit from School Feeding Program. Retrieved from https://reliefweb.int/report/ethiopia/over-13m-students-benefit-school-feeding-program 
Ghana School Feeding Programme (GSFP): Ministry of Gender, Child and Social Protection. (2017). Retrieved from http://mogcsp.gov.gh/ghana-school-feeding-programme-gsfp/

Githuku, J. (2012). Effects Of School Feeding Programme On Pupils Enrolment In Early Childhood Education In Karaba

Zone, Mbeere South District, Embu County [Ebook]. Retrieved
http://erepository.uonbi.ac.ke/bitstream/handle/11295/90427/Githuku_Effects\%20of\%20school\%20feeding\% 20program me\%20on\%20pupils\%20enrollment \%20in\%20early \% 20childhood\%20education\% 20in\% 20Karaba\% 20zone, \% 20Mbeer e\%20south\%20district, \% 20Embu\%20county.pdf?sequence=1

Githuku, J. (2012). Effects Of School Feeding Programme On Pupils Enrolment In Early Childhood Education In Karaba Zone, Mbeere South District, Embu County [Ebook]. Retrieved from http://erepository.uonbi.ac.ke/bitstream/handle/11295/90427/Githuku_Effects\%20of\%20school\%20feeding\%20program me\%20on\% 20pupils\%20enrollment \%20in\% 20early \% 20childhood\% 20education\% 20in\% 20Karaba\% 20zone, \% 20Mbeer e\% 20south\%20district, \% 20Embu \%20county.pdf?sequence=1

Githuku, J. G. (2015). Effects of School Feeding Programme on Pupils Enrolment in Early Childhood Education in Karaba Zone, Mbeere South District, Embu County. $\quad$ Unpublished Thesis University of Nairobi.

Gorard, S. (2001). Quantitative Methods in Education Research; The Role of Numbers Made Easy. Paston Prepress Limited, Beccles, Sufolk. Great Britain.

Hamupembe, E. (2016). Investigating the Administration of the School Feeding Programme: A Case Study of Two Primary Schools in Windhoek, Namibia [Ebook]. $\quad$ Retrieved http://repository.unam.na/bitstream/handle/11070/1950/hamupembe 2016.pdf?sequence=1\&isAllowed=y

Hamupembe, E. (2016). Investigating the Administration of the School Feeding Programme: A Case Study of Two Primary Schools in Windhoek, Namibia [Ebook]. $\quad$ Retrieved http://repository.unam.na/bitstream/handle/11070/1950/hamupembe_2016.pdf?sequence=1\&isAllowed=y

HGSF-Global. (2017). School Feeding Programs in Kenya: Transitioning to a Homegrown Approach. global.org/kenya/en/policy/policy-and-governance/251-home- grown-school-meals-programme-hgsmp.

Home Grown School Feeding Programme: Zambia. $\quad$ (2013). Retrieved from https://documents.wfp.org/stellent/groups/public/documents/newsroom/wfp260972.pdf?.ga=2.101711367.787044305.15326 85765-619315096.1532685765

Huitt, W. (2007). Maslow's hierarchy of needs. Educational Psychology Interactive. Valdosta, GA: Valdosta State University http://www.edpsycinteractive.org/topics/regsys/maslow.html

Huitt, W. (2007). Maslow's hierarchy of needs. Educational Psychology Interactive. Valdosta, GA: Valdosta State University http://www.edpsycinteractive.org/topics/regsys/maslow.html 
Jerome, N. (2013). Application of the Maslow's hierarchy of need theory; impacts and implications on organizational culture, human resource and employee's performance. International Journal Of Business And Management Invention, 2(31). Retrieved from https://pdfs.semanticscholar.org/b0bc/c8ca45193eaf700350a8ac2ddfc09a093be8.pdf

Kamaludeen, H. (2014). The Impact of the Ghana School Feeding Programme on Enrollment, Attendance and Retention in Ga South Municipal Schools. Retrieved from http://ugspace.ug.edu.gh/handle/123456789/7492

Karisa, K. S. \& Orodho, J. A. Assessment of Home Grown School Feeding Programme

(HGSFP) Theory in Kinango Sub-County, Kwale County, Kenya. Journal of $\quad$ Humanities And Social Science, 19(9):45-52

Khatete, I., Pendo, W., \& Oyabi, J. (2013). School Feeding Program and Pupils' Participation in Primary Schools in Kenya. A Study of Taita Taveta and Nairobi Districts. Journal Of Emerging Trends In Educational Research And Policy Studies. Retrieved from http://jeteraps.scholarlinkresearch.com/articles/School\%20Feeding.pdf

King, N., Dewey, C., \& Borish, D. (2018). Determinants of Primary School Non-Enrollment and Absenteeism: Results from a Retrospective, Convergent Mixed Methods, Cohort Study in Rural Western Kenya. PLOS, 10(9). doi: 10.1371/journal.pone.0138362

King, N., Dewey, C., \& Borish, D. (2018). Determinants of Primary School Non-Enrollment and Absenteeism: Results from a Retrospective, Convergent Mixed Methods, Cohort Study in Rural Western Kenya. PLOS, 10(9). doi: 10.1371/journal.pone.0138362

Kitui-west sub-county. (2013). DEO' Office inspection report.

Kokwee, Z. (2014). Impact of school feeding programme on participation of learners in primary school education in Mogotio district, Baringo county [Ebook]. Retrieved from http://ir-library.ku.ac.ke/handle/123456789/11246

Kombo, T. (2006). Guidelines to proposal and thesis writing. Nairobi: Paulin publication

Kristjansson et. Al (2016). Costs, and cost-outcome of school feeding programmes and feeding programmes for young children. Evidence and recommendations. International Journal of Educational Development 48:79 -83.

Krugrendo, P., \& Benson, T. (2011). Food-for-Education programs: Lessons for Uganda [Ebook]. Retrieved from https://reliefweb.int/sites/reliefweb.int/files/resources/ussppn13.pdf

Krugrendo, P., \& Benson, T. (2011). Food-for-Education programs: Lessons for Uganda [Ebook]. Retrieved from https://reliefweb.int/sites/reliefweb.int/files/resources/ussppn13.pdf

LACA. (2010). The School Flan [Ebook]. $\quad$ Retrieved http://laca.co.uk/sites/default/files/LACA \%20briefing\%20on\%20the\%20School\%20Food\% 20Plan.pdf 
Langinger, N. (2011). School Feeding Programs in Kenya: Transitioning to a Homegrown of International Relations, 13(1): 30-38

Langinger, N. (2011). School Feeding Programs in Kenya: Transitioning to a Homegrown Approach [Ebook]. Retrieved from https://www-leland.stanford.edu/group/sjir/13-1/kenya.pdf

Langinger, N. (2011). School Feeding Programs in Kenya: Transitioning to a Homegrown Approach [Ebook]. Retrieved from https://www-leland.stanford.edu/group/sjir/13-1/kenya.pdf

Lawson, M. (2012). School Feeding programmes in Developing countries. Impacts on Education Outcomes. Nutrition Review, 69. 83-98

Lawson, T. (2012). Impact of School Feeding Programs on Educational, Nutritional, and Agricultural Development Goals: A Systematic Review of Literature. Retrieved from https://ideas.repec.org/p/ags/midagr/142466.html

Mburu, P. (2012). Effectiveness of management strategies in the enhancement of Pupils' access and participation in free primary school Education in Githunguri Kiambu County [Ebook].

McEwan, P. (2013). The Impact of Chile's School Feeding Program on Education Outcomes. Retrieved from https://eric.ed.gov/?id=EJ997917

McEwan, P. (2013). The Impact of Chile's School Feeding Program on Education Outcomes. Retrieved from https://eric.ed.gov/?id=EJ997917

Meng, X., \& J. Ryan. (2004). Evaluating the food for education programme in Bangladesh. Draft report. Canberra: Australian National University.

Mhurchu, C., Gorton, D., Turley, M., Jiang, Y., Michie, J., Maddison, R., \& Hattie, J. (2012). Effects of a free school breakfast programme on children's attendance, academic achievement and short-term hunger: results from a steppedwedge, cluster randomised controlled trial. Journal Of Epidemiology And Community Health, 67(3), 257-264. doi: 10.1136/jech-2012-201540

Mhurchu, C., Gorton, D., Turley, M., Jiang, Y., Michie, J., Maddison, R., \& Hattie, J. (2012). Effects of a free school breakfast programme on children's attendance, academic achievement and short-term hunger: results from a steppedwedge, cluster randomised controlled trial. Journal Of Epidemiology And Community Health, 67(3), 257-264. doi: 10.1136/jech-2012-201540 
Migosi, J., Nanok, D., Ombuk, C., Ombuk, K., Evusa, Z., \& Metet, J. (2012). Determinants of primary school access and participation rates in the pastoralist Turkana County, Kenya. Universal Journal of Education and General Studies, 1(11). Retrieved http://repository.seku.ac.ke/bitstream/handle/123456789/43/Migosi_Determinants\%20of\%20primary\%20school...\%20.pd f?sequence $=1$ \&isAllowed $=y$

Migosi, J., Nanok, D., Ombuk, C., Ombuk, K., Evusa, Z., \& Metet, J. (2012). Determinants of primary school access and participation rates in the pastoralist Turkana County, Kenya. Universal Journal of Education and General Studies, 1(11). Retrieved http://repository.seku.ac.ke/bitstream/handle/123456789/43/Migosi_Determinants\%20of\%20primary\%20school...\%20.pd f?sequence $=1 \&$ isAllowed $=y$

Mohamed, A. (2015). Influence of feeding programs on the participation of learners at early childhood development education institutions: A case of Bungoma South district. International Academic Journal of Social Sciences and Education, 1 (4), 1-14

Mohammed, Y. (2010). The impact of school feeding programme on pupil retention in primary schools: a case of Garissa District; Kenya [Ebook].

Mohammed, Y. (2010). The impact of school feeding programme on pupil retention in primary schools: a case of Garissa District; Kenya [Ebook].

Molinas, L., \& de la Mothe, M. (2010). The multiple impacts of school feeding: a new approach for reaching sustainability [Ebook].

Molinas, L., \& de la Mothe, M. (2010). The multiple impacts of school feeding: a new approach for reaching sustainability [Ebook].

Moore, E., \& L. Kunze. (1994). Evaluation of the Burkina Faso school feeding programme. Catholic Relief Services, Consultant Report (Unpublished).

Muema, T., \& Mutegi, R. (2011). The impact of school feeding programmes on pupil retention in primary schools in Kenya [Ebook].

Mugenda, J. (2003). Research methods, African Centre for technology studies. Nairobi, Kenya.

Mugenda, O. and Mugenda A (1999). Research Methods: Qualitative and Quantitative Aprroaches. Nairobi; Africa Centre for Technology Studies Press.

Mugenda, O., \&Mugenda A. (1999). Research methods quantitative and qualitative approaches. Nairobi: Act Press, KenyaUNESCO, (1990).World Food Programme Handbook Rome UNESCO, Printing Press. 
Mukanyiriga, V. (2010). WFP Rwanda School Feeding Programme: “Food Assistance For Education” [Ebook]. Retrieved from http://file:///C:/Users/alfred\%20mwiti/Desktop/mugithi/Rwanda\%20school\%20feeding\%20snapshot\%20(1).pdf

Murungi, K. (2013). An Evaluation of the School Feeding Programme: A Case of Wamba Division, Samburu County, Kenya [Ebook]. https://erepository.mku.ac.ke/bitstream/handle/123456789/2457/MURUNGI\%20M.\%20KENNETH.pdf?sequence=1\&isA $\underline{\text { llowed }=\mathbf{y}}$

Mushonga, Kujinga, Changwena, Chituhu, \& Nyabanga. (2014). A Retrospective Study of

Musyoka. (2013).Provision of basic needs and its impacts on educational outcomes. Kenyatta University. Unpublished theses

Mutia, j. (2015). Strategic planning in public secondary schools in kitui west sub-county.

Mwavula, A. (2014). Influence Of School Feeding Programme On Pupils Participation In Public Primary Schools In Flood Prone Areas Of Garsen Division, Tana Delta District, Kenya [Ebook]. Retrieved from http://eap.uonbi.ac.ke/sites/default/files/cees/education/eap/Final\%20Project\%20-\%20Agripina.pdf

Mwavula, A. (2014). Influence Of School Feeding Programme On Pupils Participation In Public Primary Schools In Flood Prone Areas Of Garsen Division, Tana Delta District, Kenya [Ebook]. Retrieved from http://eap.uonbi.ac.ke/sites/default/files/cees/education/eap/Final\%20Project\%20-\%20Agripina.pdf

Nafula, W. (2015). Impact of School Feeding Programme on Pupils' Retention Rates in Public Primary Schools in Fafi Sub-County Garissa County Kenya. Unpublished Thesis University of Nairobi.

National School Lunch Program - Office for Food and Nutrition Programs. (2018). Retrieved from http://www.doe.mass.edu/cnp/nprograms/nslp.html

Ndingu, E. (2010). The Status Of School Feeding Programme And Implication For Access And Retention: A Case Of Primary Schools In Kamukunji District, Nairobi, Kenya. [Ebook]. Retrieved from http://irlibrary.ku.ac.ke/bitstream/handle/123456789/768/Ndungu,\%20Elizabeth\%20N.\% 20.pdf?sequence=3

Ndungu, E. (2010). The Status of School Feeding Programme and Implication for Access and Retention: A Case Of Primary Schools In Kamukunji District, Nairobi, Kenya. [Ebook]. Retrieved from $\underline{\text { http://ir- }}$ library.ku.ac.ke/bitstream/handle/123456789/768/Ndungu,\%20Elizabeth\%20N.\%20.pdf;jsessionid=876E4704624CFC45F $\underline{53 C 3512571683 F 8 ? \text { sequence }=3}$

Ngome, C. (2012). The impact of the school feeding programme on the school participation rates of primary pupils in Kajiado district, Kenya [Ebook]. Retrieved from http://ir-library.ku.ac.ke/handle/123456789/2431?show=full 
Nikema, P. (2017). Impact of school feeding programmes on educational outcomes: Evidence from dry cereals in schools in Burkina Faso [Ebook]. Retrieved from https://www.wider.unu.edu/sites/default/files/Publications/Workingpaper/PDF/wp2017-182.pdf

Nyakundi, E. M. (2017). Influence of School Feeding Program on Pupil's Retention in Public Primary Schools in Dagoretti South Sub-County, Nairobi County Kenya. Unpublished Thesis University of Nairobi.

Oduoro-Ofori, E., \& Gyapon, A. (2014). The Contribution of the Ghana Schools Feeding Programme to Basic School Participation: A Study of Selected Schools in the Kwaebibirim District of Ghana [Ebook.

Ondieki, E. (2018). What to expect as WFP cuts free food to learners. Retrieved from https://www.nation.co.ke/news/education/What-to-expect-as-WFP-cuts-free-food-to-learners/2643604-4604358Ir3omq/index.html

Orodho, j. a. (2008). Techniques of writing research proposals and reports in education and social sciences.

Orodho,J.A. (2005). Education Research for Social Science. Nairobi: Masola Publishers.

Orodho,J.A. (2004). Education Research for Social Science. Nairobi: Masola Publishers.

Otieno, D. (2014). Influence Of School Feeding Program On Academic Performance Of Pre-School Children In Kayole Zone, Nairobi County [Ebook]. Retrieved from https://cees.uonbi.ac.ke/sites/default/files/cees/dan\%20project 0.pdf

Otieno, D. (2014). Influence Of School Feeding Program On Academic Performance Of Pre-School Children In Kayole Zone, Nairobi County [Ebook]. Retrieved from https://cees.uonbi.ac.ke/sites/default/files/cees/dan\%20project_0.pdf

Oyugi, M.(2007).Research on impact of school feeding programme on performance of children in Bondo division Kenya.

Pelletier, D.L., K. Deneke, Y.Kidane, B. Haile \& F. Negussie. (1995). The food-first bias and nutritional policy. Lessons from Ethiopia. Food Policy 20(4).

Pollitt, E., M. Gersovitz, \& M. Garguilo. (1978). Educational benefits of the U.S. school feeding programme:A critical review of the literature.American Journal Public Health 68.

Powell, C.A., et al. (1998).Nutrition and education: A randomized trial of the effects of breakfast in rural primary school children.American Journal of Clinical Nutrition 68 (4). 
Ramadhan, J. (2014). An Assessment Of The Effects Of School Feeding Programmes On School Enrolment, Attendance And Academic Performance In Primary Schools In Singida District, Tanzania [Ebook]. Retrieved from http://repository.out.ac.tz/599/1/JAPHARI_KINDI_RAMADHANI.pdf

Ramadhan, J. (2014). An Assessment Of The Effects Of School Feeding Programmes On School Enrolment, Attendance And Academic Performance In Primary Schools In Singida District, Tanzania [Ebook]. Retrieved from http://repository.out.ac.tz/599/1/JAPHARI_KINDI_RAMADHANI.pdf

Reche, G.N.,Bundi,T.K, .Riungu,J,N,.\& Mbugua, Z.K (2012).Factors contributing to poor performance in Kenya Certificate of Primary Education Examinations in Public Primary SCHOOLS IN Mwimbi Division, Maara District, Kenya. International Journal of Humanities and Social Sciences.

Reinsma, K., Nkuoh, G., \& Nshom, E. (2017). Erratum to: The potential effectiveness of the nutrition improvement program on infant and young child feeding and nutritional status in the Northwest and Southwest regions of Cameroon, Central Africa. BMC Health Services Research, 17(1). doi: 10.1186/s12913-017-2109-3

Reinsma, K., Nkuoh, G., \& Nshom, E. (2017). Erratum to: The potential effectiveness of the nutrition improvement program on infant and young child feeding and nutritional status in the Northwest and Southwest regions of Cameroon, Central Africa. BMC Health Services Research, 17(1). doi: 10.1186/s12913-017-2109-3

Rocha, N., Filgueiras, M., Albuquerque, F., Milagres, L., Castro, A., \& Silva, M. et al. (2018). Analysis of the national school feeding program in the municipality of Viçosa, state of Minas Gerais. Revista De Saúde Pública, 52, 16. doi: 10.11606/s1518-8787.2018052007090

Rocha, N., Filgueiras, M., Albuquerque, F., Milagres, L., Castro, A., \& Silva, M. et al. (2018). Analysis of the national school feeding program in the municipality of Viçosa, state of Minas Gerais. Revista De Saúde Pública,52, 16. doi: 10.11606/s1518-8787.2018052007090

Saeni, J. (2015). An Evaluation Of The Impact Of School Feeding Programme On Retention In Learning Of Ecde Children In Kilgoris Constituency, Narok County, Kenya.[Ebook]. Retrieved from http://41.89.101.166:8080/xmlui/bitstream/handle/123456789/390/JOHN\%20MASIANTET\%20OLE\%20SAENI.pdf?sequ ence $=1 \&$ isAllowed $=\mathbf{y}$

Salee, D. (2013). Influence Of School Feeding Program On Pupils' Participation In Public Primary Schools In Masinga Division In Machakos County, Kenya[Ebook]. $\quad$ Retrieved http://erepository.uonbi.ac.ke/bitstream/handle/11295/55899/Mutua_Influence\%20Of\%20School\%20Feeding\%20Progra m\%200n\%20Pupils\%E2\% 80\% 99\%20Participation\%20In\%20Public\% 20Primary\%20Schools\% 20In\% 20Masinga\%20 Division \% 20In\%20Machakos\% 20County \%2C\%20Kenya.pdf?sequence=3\&isAllowed $=\mathbf{y}$

Sanya, H. (2015). Impact of Feeding on Student Attendance in Secondary School: Case of Kiteto District in Tanzania. Unpublished Thesis University of Tanzania. 
School meals | World Food Programme. (2017). Retrieved from http://www1.wfp.org/school-meals

State of School Feeding Worldwide | WFP | United Nations World Food Programme - Fighting Hunger Worldwide. (2017). Retrieved from http://www.wfp.org/content/state-school-feeding-worldwide-2013

Tanzania: 200,000 Pupils Benefit From 'Food for Education' | WFP | United Nations World Food Programme - Fighting Hunger Worldwide. (2017). Retrieved from https://www.wfp.org/content/tanzania-200000-pupils-benefit-food-education

Taylor, A. D., \& Ogbogu, C. O. (2016). The Effects of School Feeding Programme on Enrolment and Performance of Public Elementary School Pupils in Osun State, Nigeria. World Journal of Education, 6(3):39-47.

The Nutritional Status Of Primary School Children In HararE. African Journal of Food, Agriculture, And Development, 14(3). Retrieved from https://www.ajfand.net/Volume14/No3/Mushonga13360.pdf

UNESCO. (2002).The world education forum, Education for All. Dark, Senegal

WOrld Food Programme. (2001).Global school feeding campaign into school out of hunger, WFP publisher affairs service. Rome Italy.

Wekesa, K. (2011). Impact Of School Feeding Programme On Pupils' Retention Rates In Public Primary Schools In Fafi Sub-County Garissa County Kenya [Ebook].

WFP, 2016. Home Grown School Meals Benefit Children, Farmers and Communities

WFP. (2001).Operational contract between the government of Kenya and the world food programme, Kenya country ptogramme, government Press. Nairobi.

WFP. (2005). Consolidated framework of WFP policies. Rome.

WFP. (2006).Reviewing the evidence: Food for education experts' seminar. Rome.

World Bank. (2006). Repositioning nutrition as central to development. Washington, D.C.

World Food Programme. (2001). Global school feeding campaign into school out of hunge. WFP, Public Affairs Service, Rome Italy. 
World Food Programme: Two Minutes to Learn about School Meal. (2013). Retrieved from https://docs.wfp.org/api/documents/WFP-0000024054/download/

World Food Programme: Two Minutes to Learn about School Meal. (2012). Retrieved from https://docs.wfp.org/api/documents/WFP-0000024054/download/

Yasin, J. (2013). School Feeding Programmes in Chimutu, Malawi: Opportunities, Benefits and Challenges. [Ebook]. Retrieved from http://libdspace.ufh.ac.za/bitstream/handle/20.500.11837/522/kntix\% 20Final\% 20Dissertationsigned.pdf?sequence $=1$ \&isAllowed $=y$

Yasin, J. (2013). School Feeding Programmes in Chimutu, Malawi: Opportunities, Benefits and Challenges. [Ebook].

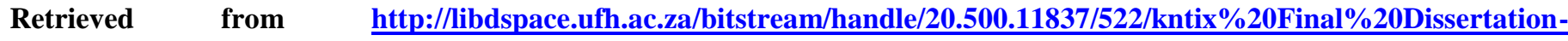
signed.pdf?sequence $=1$ \&isAllowed $=y$

Yendaw, E., \& Dayour, F. (2015). Effect of the National School Feeding Programme on Pupils' Enrolment, Attendance and Retention: A Case Study of Nyoglo of the Savelugu-Nantong Municipality, Ghana. British Journal Of Education, Society \& Behavioural Science, 5(3), 341-353. doi: 10.9734/bjesbs/2015/14271

Zenebe, M., Gebremedhin, S., Henry, C., \& Regassa, N. (2018). School feeding program has resulted in improved dietary diversity, nutritional status and class attendance of school children. Italian Journal Of Pediatrics, 44(1). doi: 10.1186/s13052-018-0449-1 